\title{
Gene disruption and replacement in the rapamycin-producing Streptomyces hygroscopicus strain ATCC 29253
}

\author{
Natalie Lomovskaya, ${ }^{1}$ Leonid Fonstein, ${ }^{1}$ Xiaoan Ruan, ${ }^{3}$ Diane Stassi, ${ }^{3}$ \\ Leonard $\mathrm{Katz}^{3}$ and $\mathrm{C}$. Richard Hutchinson ${ }^{1,2}$
}

Author for correspondence: C. Richard Hutchinson. Tel: +1 608262 7582. Fax: +1 6082623134. e-mail: crhutchi@facstaff.wisc.edu

1,2 School of Pharmacy ${ }^{1}$ and Department of Bacteriology2, University of Wisconsin, Madison, WI 53706, USA

${ }^{3}$ Antiinfective Discovery Research, Abbott Labs, Abbott Park, IL 60064, USA

\begin{abstract}
A system for gene disruption and replacement based on a streptomycete temperate phage vector was developed to introduce DNA in the rapamycinproducing Streptomyces hygroscopicus strain ATCC 29253. This will be useful in attempts to produce, through genetic manipulation, novel forms of the therapeutically important immunosuppressive drug rapamycin. Recombinant phages were constructed from the $\phi \mathrm{C} 31$ phage derivative $\mathrm{KC5} 15$ ( $\mathrm{c}^{+}$attP) carrying a thiostrepton or viomycin resistance gene along with segments of the $S$. hygroscopicus chromosome. Each of the cloned segments also contained the aphIl neomycin/kanamycin resistance gene to enable gene replacement by loss of the phage-derived DNA. Specific deletion of the entire polyketide synthase (PKS) believed to govern rapamycin biosynthesis resulted in the loss of rapamycin production. In contrast, disruption or deletion of a region predicted to encode four PKS open reading frames, or another region predicted to encode another PKS plus a cytochrome P450 hydroxylase and ferredoxin, had no effect on the production of rapamycin or nigericin, a polyether antibiotic also produced by $\mathbf{S}$. hygroscopicus. Therefore, $S$. hygroscopicus may have the capacity to produce polyketides additional to rapamycin and nigericin.
\end{abstract}

Keywords: nigericin, polyketide, modular polyketide synthase, Streptomyces bygroscopicus

\section{INTRODUCTION}

Streptomyces hygroscopicus ATCC 29253, the rapamycin producer, was originally isolated during screening for antifungal compounds (Vezina et al., 1975). It was later found that rapamycin has valuable immunosuppressive activity (Melino \& Sigal, 1990; Dumont \& Su, 1996). Rapamycin, FK506 (Kino et al., 1987) and FK520 (Hatanaka et al., 1988) belong to a group of macrocyclic polyketides with greater immunosuppressive potency than cyclosporin A, the principal drug currently available. However, since rapamycin as well as cyclosporin A are not devoid of in vivo toxicity, a need still exists to discover less toxic immunosuppressive agents. One approach is to make $S$. hygroscopicus produce structural analogues of rapamycin through targeted mutation of the genes for rapamycin biosynthesis (Schwecke et al., 1995). Structural ana-

Abbreviation: PKS, polyketide synthase. logues of several polyketide antibiotics have been obtained in this way (Katz \& Donadio, 1993; Hutchinson, 1994; Hutchinson \& Fujii, 1995), most notably by targeted mutation of the polyketide synthase (PKS) genes for erythromycin biosynthesis (Donadio et al., 1993; Kao et al., 1994; Cortes et al., 1995). The same approach is applicable to rapamycin since its biosynthesis appears to involve a modular (type I) PKS (Schwecke et al., 1995), but this first requires a means to introduce DNA into the rapamycin-producing strain.

After discovering that the commonly used methods of transformation with plasmid DNA or conjugal transfer were unsuccessful with the rapamycin-producing strain (G. Meurer, N. Lomovskaya, N. Yang, X. Ruan \& D. Stassi, unpublished), we examined vectors made from the temperate phage $\phi \mathrm{C} 31$ (Lomovskaya et al., 1972, 1980; Chater, 1986). Such vectors have been successfully used for cloning antibiotic biosynthetic genes (Chater \& Bruton, 1983, 1985) and genes responsible for morphological development (Piret \& Chater, 1985; Mendez 
\& Chater, 1987), as well as for disrupting RNA polymerase sigma factor and ppGpp synthetase genes (Buttner et al., 1990; Buttner \& Lewis, 1992; Chakraburtty et al., 1996), largely in Streptomyces coelicolor A3(2). Using the $c^{+}$attP-deleted $\phi \mathrm{C} 31$ derivative KC515 (Chater, 1986; Hopwood et al., 1987) for both gene disruption and replacement, we studied the role of the modular PKS reported by Schwecke et al. (1995) in rapamycin biosynthesis as well as that of two other regions of S. bygroscopicus DNA containing apparent modular PKS genes. One region appears to encode a PKS consisting of four multifunctional proteins, and the other to encode portions of a PKS associated with genes for a cytochrome P450 hydroxylase and ferredoxin (X. Ruan, D. L. Stassi, N. Lomovskaya, L. Fonstein, C. R. Hutchinson \& L. Katz, unpublished).

\section{METHODS}

Bacterial strains, plasmids and phages. Escherichia coli strain DH5x (Sambrook et al., 1989) and E. coli vectors pUC18 (Yanisch-Perron et al., 1985), pGEM7Zf(-), pGEM9Zf(-) and pSP72 (Promega) were used for routine subcloning. The Streptomyces strains, plasmids and phages used in this study are listed in Table 1.

Biochemicals and chemicals. Thiostrepton was a gift from S. J. Lucania (E. R. Squibb \& Sons, Princeton, NJ, USA), and rapamycin and nigericin were obtained from Jim McAlpine (Abbott Laboratories, Abbott Park, IL, USA). Restriction enzymes and other molecular biology reagents were from commercial sources.

Media and growth conditions. E. coli strains carrying plasmids were grown in Luria-Bertani medium (Sambrook et al., 1989), and were selected with ampicillin $\left(100 \mu \mathrm{g} \mathrm{ml}^{-1}\right) . S$. bygroscopicus and S. lividans TK24 (Hopwood et al., 1983) strains were grown on MOM medium [containing, per litre: bacto-oatmeal agar ISP3 (Difco), $11 \mathrm{~g}$; cerelose, $4 \mathrm{~g} ; \mathrm{N}-\mathrm{Z}$ casamino acids, $0.2 \mathrm{~g}$; molasses, $1 \mathrm{~g} ; \mathrm{NaCl}, 1 \mathrm{~g}$; Difco agar, $16 \mathrm{~g}$ ] and on R2YE medium (Hopwood et al., 1985) without sucrose for sporulation, and at $30^{\circ} \mathrm{C}$ in $\mathrm{R} 2 \mathrm{YE}$ liquid medium (Hopwood et al., 1985) for preparation of protoplasts and isolation of chromosomal DNA. $\phi \mathrm{C} 31$ and its derivatives were propagated as described by Hopwood et al. (1985) or in liquid medium containing, per litre: nutrient broth (Difco), $8 \mathrm{~g}$; $\mathrm{NaCl}, 9 \mathrm{~g}$. The following nutrients were added after autoclaving: $1 \mathrm{M} \mathrm{MgSO}_{4} .7 \mathrm{H}_{2} \mathrm{O}, 10 \mathrm{ml} ; 0.8 \mathrm{M} \mathrm{Ca}\left(\mathrm{NO}_{3}\right)_{2}, 10 \mathrm{ml}$, and a $50 \%$ solution of glucose, $20 \mathrm{ml}$. MOM agar medium was adapted for infection of $S$. hygroscopicus with $\phi \mathrm{C} 31$ derivatives by adding, per litre, $\mathrm{NaCl}, 4.5 \mathrm{~g}$, and (after autoclaving) $1 \mathrm{M} \mathrm{MgSO}_{4} .7 \mathrm{H}_{2} \mathrm{O}, 10 \mathrm{ml}, 0.8 \mathrm{M} \mathrm{Ca}\left(\mathrm{NO}_{3}\right)_{2}$, $10 \mathrm{ml}$. The minimal medium (MM) used was from Hopwood et al. (1985).

Isolation and in vitro manipulation of DNA. Plasmid DNA was isolated from bacterial cells with the Bio101 RPM kit. $\phi$ C31 phage DNA was isolated with the Qiagen lambda kit. Total S. hygroscopicus DNA was isolated by the protocol of Hopwood et al. (1985). Restriction endonuclease digestions and ligations used standard techniques (Sambrook et al., 1989). DNA fragments for labelling and subcloning were isolated with the Qiaex (Qiagen) gel extraction kit. The conditions for phage DNA transfection were as described by Hopwood et al. (1985).
Southern blot analysis. Streptomyces chromosomal DNA was digested with restriction enzymes for $4 \mathrm{~h}$, electrophoresed in a $0.8 \%$ agarose gel overnight and blotted to Hybond $\mathrm{N}$ membranes (Amersham) by capillary transfer (Sambrook et al., 1989). Labelling, hybridization and detection were carried out with the Genius 1 non-radioactive DNA labelling kit (Boehringer Mannheim) according to the manufacturer's instructions.

Cloning of S. hygroscopicus DNA segments by PCR methods. To create recombinant phage phWHM275, the $1.2 \mathrm{~kb}$ Pst IXbaI fragment 4 (Fig. 2b) was amplified by the PCR method using the following two primers, $5^{\prime}$-GCGCTGCAGCCGGAAACTTCCTCAGCCTG-3' and 5'-GCGTCTAGAGCGTCATCCTGCCCGCCATC-3'. Similarly, phWHM276 was constructed from the $1.68 \mathrm{~kb} \mathrm{BamHI-Xbal} \mathrm{fragment} 6$ (Fig. 3a) using the following two primers, $5^{\prime}$-GCGGGATCCATCAGCGTCTTCGGGTGAAT- ${ }^{\prime}$ and $5^{\prime}$-GCGTCTAGATTCAAGGATTTGGGTGTGGA- $3^{\prime}$; and $1.33 \mathrm{~kb} X b a \mathrm{I}-P s t \mathrm{I}$ fragment 7 (Fig. 3a) using the following two primers, 5'-GCGTCTAGATCGTGGATGACACCCTCTAC-3' and 5'-GCGCTGCAGTCTTATTCGTTCCTGGTCCT-3'. To confirm the gene replacements in the WMH1651 and WMH1652 strains the following primers were used: 5'-GCGGGATCCTGCCATTTATTCAGAACCGA-3' and 5'-GCGAAGCTTATCAGAGTGGTGACGTTTTC-3'. All PCR mixtures contained thermo DNA poly react buffer (Promega), $2.5 \mathrm{mM} \mathrm{MgCl}_{2}, 50 \mathrm{ng}$ chromosomal DNA and $0.5 \mu \mathrm{g}$ of each pair of primers in a total volume of $91 \mu \mathrm{l}$. The PCR reaction was carried out in a model 480 DNA Thermal Cycler (Perkin-Elmer Cetus). The reaction mixture was overlaid with mineral oil and incubated at $100{ }^{\circ} \mathrm{C}$ for $5 \mathrm{~min}$, then cooled to $70^{\circ} \mathrm{C}$ ( $3 \mathrm{~min}$ ), and $2.5 \mathrm{U}$ of $\mathrm{Taq}$ polymerase (Promega) and $60 \mu \mathrm{M} \mathrm{dCTP}$ and dGTP, and $40 \mu \mathrm{M} \mathrm{dATP}$ and dTTP were added. Amplification was achieved with 25 cycles of denaturation at $97^{\circ} \mathrm{C}$ for $1.5 \mathrm{~min}$ followed by annealing and extension at $70^{\circ} \mathrm{C}$ for $3.5 \mathrm{~min}$, then the mixture was incubated for $10 \mathrm{~min}$ at $72{ }^{\circ} \mathrm{C}$. The resulting PCR fragments were purified with the Qiagen PCR purification kit, digested with Pst I and XbaI (fragment 4), Bam HI and XbaI (fragment 6) or $X b a \mathrm{I}$ and $P s t \mathrm{I}$ (fragment 7 ), recovered from a $0.8 \%$ agarose gel after electrophoresis and cloned into plasmid vectors.

Construction of KC515-derived phages for insert-directed homologous recombination in S. hygroscopicus. For the first construct, phWHM261 ( $\phi$ C31 derivatives in this work are prefixed with 'ph'), a $4.2 \mathrm{~kb}$ EcoRI fragment, which included the sequence encoding the putative coenzyme A ligase domain of the first ORF shown in Fig. 1(a), was subcloned from cosmid pAL58 into pUC18 to create pAL4.2E. A $2 \cdot 2 \mathrm{~kb}$ XhoI-BamHI fragment of pWHM253 containing the $1 \cdot 1 \mathrm{~kb}$ $X h o I-K p n I$ internal fragment 1 from the coenzyme A ligase domain (Fig. 1a) and the aphII gene from pFDNeoS (Denis \& Brzezinski, 1991) was ligated with XhoI- and BamHI-digested KC515 to give phWHM261 (Fig. 1b) via plasmids pWHM249, pWHM252 and pWHM253, as described in Table 1.

The second construct, phWHM262, contained fragments 2 and 3 (Fig. 1a) located $10.9 \mathrm{~kb}$ from each other in the cluster defined by cosmid pAL58 with the aphII gene inserted between them. This construct was expected to be able to generate neomycin-resistant clones of $S$. hygroscopicus due to a double recombination event that would delete $10 \cdot 1 \mathrm{~kb}$ to eliminate parts of the putative ORF1 and ORF3 genes and all of ORF2 (Fig. 1a). A $4 \cdot 4 \mathrm{~kb}$ Xhol-BamHI fragment from pWHM259 containing the $1.55 \mathrm{~kb}$ Sall fragment 2 and $1.7 \mathrm{~kb}$ EcoRI fragment 3 (Fig. 1a) with the aphll gene between them was 
ligated with $\mathrm{KC} 515$ digested with $\mathrm{BamHI}$ and $\mathrm{XhoI}$ to give phWHM262 (Fig. 1b) via plasmids pWHM254 to pWHM259, as described in Table 1.

The third construct, phWHM275, was intended to replace a portion of the second PKS cluster (Fig. 2a) and contained two fragments, 4 and 5 , located $1.8 \mathrm{~kb}$ from each other in the gene cluster defined by cosmid pAL32 (Fig. 2a) and separated by the aphII gene. A $3.7 \mathrm{~kb}$ PstI-SstI fragment from $\mathrm{pWHM} 285$ containing $1.2 \mathrm{~kb}$ PstI-XbaI PCR fragment 4 (Fig. 2a), the $a p h \mathrm{II}$ gene and $1.4 \mathrm{~kb} K p n \mathrm{I}-A p a \mathrm{I}$ fragment 5 (Fig. 2a) was ligated with KC515 digested with PstI and SstI to give phWHM275 (Fig. 2b) via plasmids pWHM281 to pWHM285, as described in Table 1.

The fourth construct, phWHM276, contained the $1.68 \mathrm{~kb}$ BamHI-XbaI fragment 6 and $1.33 \mathrm{~kb}$ Xbal-PstI fragment 7 (Fig. 3a), located $78.4 \mathrm{~kb}$ apart in the cluster of rapamycin biosynthesis genes (Schwecke et al., 1995). The aphIl gene was inserted between them to give the $4 \cdot 1 \mathrm{~kb}$ Bam HI-PstI fragment cloned in pWHM288, through the intermediate plasmids pWHM286 to pWHM288 (Table 1). This BamHI-PstI segment was moved into KC515, resulting in phWHM276 (Fig. $3 \mathrm{~b})$ by replacement of the $1.3 \mathrm{~kb} \mathrm{BamHI}-P s t \mathrm{I}$ fragment of KC515 that contains the $v p h$ gene. phWHM276 enabled the isolation of neomycin-resistant $S$. bygroscopicus clones as a result of double crossover recombination, to produce a $78.4 \mathrm{~kb}$ deletion eliminating all of rapA and rapP and most of rapB and $\operatorname{rapC}$ (Fig. 3a).

Protoplasts of S. lividans TK24 were transfected with each of the phage constructs and plaques were observed after overnight incubation. The four different recombinant phages containing DNA cloned from pAL58, pAL32 or S. bygroscopicus (Table 1) were isolated by a convenient spot-test method we had developed (Lomovskaya et al., 1996). Single plaques were transferred to $0.2 \mathrm{ml}$ Difco nutrient broth and $10 \mu \mathrm{l}$ from each sample was pipetted as spots on plates overlaid with soft R2YE agar containing a mixture of $S$. lividans TK24 and S. lividans ( $\phi$ C31) lysogen spores. After $17 \mathrm{~h}$ incubation at $30^{\circ} \mathrm{C}$ the plates were overlaid with soft agar containing neomycin. Infection with phages carrying the aphII gene resulted in spots of neomycin-resistant growth after another overnight incubation at $30^{\circ} \mathrm{C}$. The recombinant phages were purified through a second round of the spot-test and the presence of the aphIl and $v p h$ or $t s r$ resistance markers was confirmed. High-titre phage stocks were then prepared and tested for the presence of the selectable resistance markers $t s r, v p h$ and $a p h I l$ by the spot-test.

The recombinant phages were screened by selecting for neomycin $(a p h I I)$ resistance with neomycin $\left(10 \mu \mathrm{g} \mathrm{ml}^{-1}\right)$ added to R2YE growth medium. The presence or absence of the $a p h l l$, viomycin $(\nu p h)$ or thiostrepton $(t s r)$ resistance genes in the phage vector was tested by adding neomycin $\left(10 \mu \mathrm{g} \mathrm{ml}^{-1}\right.$ ), viomycin $\left(200 \mu \mathrm{g} \mathrm{m}^{-1}\right)$ or thiostrepton $\left(30 \mu \mathrm{g} \mathrm{ml}^{-1}\right)$ to R2YE medium. In this way the recombinant phages phWHM261 and phWHM262 (Fig. 1b) were characterized as containing aphll and $v p h$ resistance genes, and phages phWHM275 (Fig. 2b) and pWHM276 (Fig. 3b) as containing aphll and tsr resistance genes. The presence of the cloned DNA was confirmed by restriction endonuclease digestion analysis.

Screening of S. hygroscopicus recombinant clones. S. hygroscopicus was infected with recombinant phages on supplemented MOM agar plates $\left(5 \times 10^{7}\right.$ spores and 1 to $2 \times 10^{8}$ phage) to allow phage multiplication and host sporulation. After $16 \mathrm{~h}$ the plates were overlaid with an aqueous neomycin solution to give a final concentration of $10 \mu \mathrm{g} \mathrm{ml}^{-1}$, then after further growth for $7 \mathrm{~d}$ until sporulation, the clones were replica-plated on MM containing neomycin. Primary neomycin-resistant clones were isolated and their phenotype was determined after a second round of single colony isolation. Selection for phage vector integration or gene replacement was carried out on $\mathrm{MM}$ with neomycin $\left(10 \mu \mathrm{g} \mathrm{m}^{-1}\right)$, viomycin $\left(30 \mu \mathrm{g} \mathrm{ml}^{-1}\right)$ or thiostrepton $\left(30 \mu \mathrm{g} \mathrm{ml}^{-1}\right)$.

Bioassays for rapamycin and nigericin production. The agar plug method was used to assay recombinant clones growing on MOM agar medium, using A. niger grown on Bacto dextrose agar and $S$. aureus grown on Bacto antibiotic medium 1 (Difco). To assay for rapamycin and nigericin specifically, MOM agar with 7-d-old S. hygroscopicus cultures was steeped in 0.5 vol. acetone for $2 \mathrm{~h}$ at room temperature. The resulting leachate was extracted with $0.5 \mathrm{vol}$. isopropyl acetate for $2 \mathrm{~h}$ and concentrated in vacuo. Rapamycin and nigericin were detected by TLC on silica gel using ethyl acetate/ methanol/water (100:2.5:1, by vol.) as a solvent system, and visualized by spraying the air-dried plates with a solution containing, per litre, ceric sulfate, $10 \mathrm{~g}$; ammonium molybdate, $25 \mathrm{~g}$; concentrated $\mathrm{H}_{2} \mathrm{SO}_{4}, 100 \mathrm{ml}$; water, to 11 . Heating at $105^{\circ} \mathrm{C}$ for 2 min developed the coloration. Alternatively, the dried TLC plates were bioassayed by overlaying them with Bacto potato dextrose agar or Bacto antibiotic medium 1 (Difco) containing Aspergillus niger spores or a Staphylococcus aureus overnight culture, then incubated overnight at $33^{\circ} \mathrm{C}$ or $37^{\circ} \mathrm{C}$, respectively. TLC plates were examined for nigericin by a red blood cell lysis bioassay developed for the identification of polyether antibiotics (Ray Yao, Eli Lilly and Company, personal communication); in this assay, plates were overlaid with $\mathrm{NaCl}$ agar $(0.85 \% \mathrm{NaCl}$ and $1.5 \%$ agar) containing defibrinated horse blood (Colorado Serum Company) and incubated overnight at $37^{\circ} \mathrm{C}$ to develop the zones of cell lysis.

\section{RESULTS AND DISCUSSION}

\section{Interaction of $\phi \mathrm{C} 31$ and its derivatives with $S$. hygroscopicus}

Wild-type $\phi \mathrm{C} 31$ phage infected S. hygroscopicus and formed plaques on a $S$. hygroscopicus lawn. A small reduction in efficiency of plating compared to S. lividans was observed when the phage was assayed on $S$. bygroscopicus and this did not depend on whether $S$. lividans TK24 or S. hygroscopicus was the previous host. In contrast, the att $P^{+} \phi \mathrm{C} 31$ derivatives $\phi \mathrm{C} 31 \mathrm{R} 3$ and $\phi \mathrm{C} 31 \mathrm{R} 8$ (Chater et al., 1986) as well as attP $\phi \mathrm{C} 31$ derivatives KC400, KC500 and KC515 (Chater, 1986) did not give visible plaques on $S$. hygroscopicus.

Additional evidence of infection by these vectors was obtained by demonstrating the formation of $S$. hygroscopicus lysogens. After infection with $\phi \mathrm{C} 31 \mathrm{R} 3$ att $P^{+}:: t s r:: \nu p h$ or $\phi \mathrm{C} 31 \mathrm{R} 8$ att $P^{+}:: t s r$, lysogens resistant to thiostrepton and viomycin (WMH1591) or thiostrepton alone (WMH1592) were obtained, respectively. The WMH1591 and WMH1592 lysogens released $\phi \mathrm{C} 31 \mathrm{R} 3$ or $\phi \mathrm{C} 31 \mathrm{R} 8$ phages at a rate of $3.7 \times 10^{-6}$ to $8.3 \times 10^{-7}$ as a result of spontaneous induction. When a WMH1592 lysogen was superinfected with the KC515 attP phage, double lysogens (WMH1593 is a representative) were obtained as a result of homologous recombination between the resident prophage and superinfecting phage. 
Table 1. Bacterial strains, plasmids and phages

\begin{tabular}{|c|c|c|}
\hline Strain, plasmid or phage & Genotype & Source* \\
\hline \multicolumn{3}{|l|}{ Strains } \\
\hline \multicolumn{3}{|l|}{ S. hygroscopicus } \\
\hline ATCC 29253 & Wild-type & ATCC \\
\hline WMH1591 & $\phi \mathrm{C} 31 \mathrm{R} 3 \mathrm{c}^{+} a t t P^{+}:: t s r:: v p h$ lysogen & \\
\hline WMH1592 & $\phi \mathrm{C} 31 \mathrm{R} 8 \mathrm{c}^{+} a t t P^{+}:: t s r$ lysogen & \\
\hline WMH1593 & $\begin{array}{l}\phi \mathrm{C} 31 \mathrm{R} 8 \mathrm{c}^{+} a t t P^{+}:: t s r \text { and } \phi \mathrm{C} 31 \mathrm{KC} 515 \mathrm{c}^{+} \Delta a t t P:: t s r:: v p h \\
\text { double lysogen }\end{array}$ & \\
\hline WMH1597 & $a p h I I \nu p h$; obtained after infection with phWHM261 & \\
\hline WMH1598 & apblI; obtained after infection with phWHM262 & \\
\hline WHM1651 to WHM1653 & aphII; obtained after infection with phWHM276 & \\
\hline \multicolumn{3}{|l|}{ S. lividans } \\
\hline TK24 & $\mathrm{SLP}^{-}{ }^{-} \mathrm{SLP} 2^{-}$, str & Hopwood et al. (1983) \\
\hline WMH1594 & SLP1- $^{-}$SLP2- $^{-}$, str, $\phi \mathrm{C} 31$ lysogen & \\
\hline \multicolumn{3}{|l|}{ Staphylococcus aureus } \\
\hline WMH1641 & Wild-type & University of Wisconsin \\
\hline Aspergillus niger & Wild-type & Tom Leonard, Madison, WI \\
\hline \multicolumn{3}{|l|}{ Plasmids } \\
\hline pFDNeoS & pUC18 containing the aphII gene & Denis \& Brzezinski (1991) \\
\hline pAL58 & $\begin{array}{l}\text { Cosmid } 58 \text { containing a } 37 \mathrm{~kb} \text { fragment of the } S \text {. bygroscopicus } \\
\text { chromosome }\end{array}$ & \\
\hline pAL4.2E & A $4 \cdot 2 \mathrm{~kb}$ EcoRI fragment cloned from pAL58 into pUC18 & \\
\hline pWHM249 & XhoI site eliminated from $a p h I I$ gene of pFDNeoS & \\
\hline pWHM252 & $\begin{array}{l}\text { A } 1.1 \mathrm{~kb} X h o l-K p n I \text { fragment cloned from pAL } 4.2 \mathrm{E} \text { in } \\
\text { pGEM } 7 \mathrm{Zf}(-)\end{array}$ & \\
\hline pWHM253 & $\begin{array}{l}\text { A } 1 \cdot 1 \mathrm{~kb} \text { BamHI-HindIII fragment with aphII gene cloned from } \\
\text { pWHM249 in pWHM252 }\end{array}$ & \\
\hline pWHM254 & A $1.7 \mathrm{~kb}$ EcoRI fragment cloned from pAL58 in pGEM9Zf $(-)$ & \\
\hline pWHM255 & Bam HI site eliminated from pAL1.7E & \\
\hline pWHM256 & $\begin{array}{l}\text { A } 1.7 \mathrm{~kb} \text { EcoRI fragment as HindIII-Xhol fragment cloned from } \\
\text { pWHM255 in pGEM7Zf }(-)\end{array}$ & \\
\hline pWHM257 & A $1.55 \mathrm{~kb}$ SalI fragment cloned from pAL4.2E into pUC18 & \\
\hline pWHM258 & $\begin{array}{l}\text { A } 1.55 \mathrm{~kb} \text { SalI fragment as BamHI-HindIII fragment cloned from } \\
\text { pWHM257 into pWHM256 }\end{array}$ & \\
\hline pWHM259 & $\begin{array}{l}\text { A } 1 \cdot 1 \mathrm{~kb} \text { Bam HI-HindIII fragment cloned blunt-ended from } \\
\text { pWHM } 249 \text { in the filled-in HindIII site of pWHM } 258\end{array}$ & \\
\hline pAL32 & $\begin{array}{l}\text { Cosmid } 32 \text { containing a } 38 \mathrm{~kb} \text { fragment of the } S \text {. bygroscopicus } \\
\text { chromosome }\end{array}$ & \\
\hline pWHM281 & $\begin{array}{l}\text { A } 1.2 \mathrm{~kb} \text { PstI-XbaI PCR fragment cloned from S. hygroscopicus } \\
\text { chromosome into } \mathrm{pSP} 72 \text { with eliminated SstI site }\end{array}$ & \\
\hline pWHM282 & $\begin{array}{l}\text { A } 1.2 \mathrm{~kb} \text { PstI-XbaI PCR fragment with eliminated SstI site cloned } \\
\text { into pSP72 }\end{array}$ & \\
\hline $\mathrm{pWHM} 283$ & A $1.8 \mathrm{~kb} K p n \mathrm{I}-P s t \mathrm{I}$ fragment cloned from pAL32 into pSP72 & \\
\hline pWHM284 & $\begin{array}{l}\text { A } 1.4 \mathrm{~kb} K p n \mathrm{I}-A p a \mathrm{I} \text { fragment cloned from pWHM283 into } \\
\text { pGEM7Zf }(-) \text {, containing aphII gene between SmaI and HindIII } \\
\text { sites }\end{array}$ & \\
\hline pWHM285 & $\begin{array}{l}\text { A } 2.5 \mathrm{~kb} \text { ApaI-PstI fragment cloned from pWHM } 284 \text { blunt-ended } \\
\text { in filled-in KpnI site of pWHM } 282\end{array}$ & \\
\hline pWHM286 & $\begin{array}{l}\text { A } 1.68 \mathrm{~kb} \text { Bam } \mathrm{HI}-X b a \mathrm{I} \text { PCR fragment cloned from } S \text {. } \\
\text { bygroscopicus chromosome into pSP72 }\end{array}$ & \\
\hline pWHM287 & $\begin{array}{l}\text { A } 1.33 \mathrm{~kb} \text { XbaI-PstI PCR fragment cloned from S. bygroscopicus } \\
\text { chromosome into pWHM } 286\end{array}$ & \\
\hline pWHM288 & $\begin{array}{l}\text { A } 1 \cdot 1 \mathrm{~kb} \text { SalI-fragment containing aphII gene cloned from } \\
\text { pWHM249 blunt-ended in filled-in NruI site of pWHM287 }\end{array}$ & \\
\hline
\end{tabular}


Table 1. cont.

\begin{tabular}{|c|c|c|}
\hline Strain, plasmid or phage & Genotype & Source \\
\hline \multicolumn{3}{|l|}{ Phages } \\
\hline$\phi \mathrm{C} 31$ & Wild-type, $\mathrm{c}^{+}$att $P^{+}$ & Lomovskaya et al. (1972) \\
\hline $\mathrm{KC} 400$ & $\mathrm{c}^{+} \Delta a t t P:: v p h$ & Chater (1986) \\
\hline KC500 & $\mathrm{c}^{+} \Delta a t t P:: t s r:: v p h$ & Chater (1986) \\
\hline KC515 & $\mathrm{c}^{+} \Delta a t t P:: t s r:: v p h$ & Chater (1986) \\
\hline$\phi \mathrm{C} 31 \mathrm{R} 8$ & $\mathrm{c}^{+} a t t P^{+}:: t s r$ & Chater et al. (1986) \\
\hline phWHM261 & $\begin{array}{l}\mathrm{c}^{+} \Delta a t t P:: \nu p h:: 2 \cdot 2 \mathrm{~kb} \text { XhoI-BamHI fragment : :aphll; a } 2 \cdot 2 \mathrm{~kb} \\
\text { XhoI-BamHI fragment cloned from pWHM } 253 \text { in KC515 }\end{array}$ & \\
\hline phWHM262 & $\begin{array}{l}\mathrm{c}^{+} \Delta a t t P:: \nu p h:: 4.35 \mathrm{~kb} \text { XhoI-BamHI fragment: :aphII; a } 4.35 \mathrm{~kb} \\
\text { XhoI-BamHI fragment from pWHM259 cloned in KC515 }\end{array}$ & \\
\hline phWHM275 & $\begin{array}{l}\mathrm{c}^{+} \Delta a t t P:: t s r:: 3.7 \mathrm{~kb} \text { Pst } \mathrm{I}-S s t \mathrm{I} \text { fragment: }: a p h I I ; \text { a } 3.7 \mathrm{~kb} \text { Pst } \mathrm{I}-S_{s t} \mathrm{I} \\
\text { fragment from pWHM285 cloned in KC515 }\end{array}$ & \\
\hline phWHM276 & $\begin{array}{c}\mathrm{c}^{+} \Delta a t t P:: t s r:: 4 \cdot 1 \mathrm{~kb} \text { BamHI-PstI fragment : : aphII; a } 4 \cdot 1 \mathrm{~kb} \\
\text { BamHI-PstI fragment from pWHM } 288 \text { cloned in KC515 }\end{array}$ & \\
\hline
\end{tabular}

* Where no source or reference is listed, strains, plasmids and phages were derived in this study.

(a)

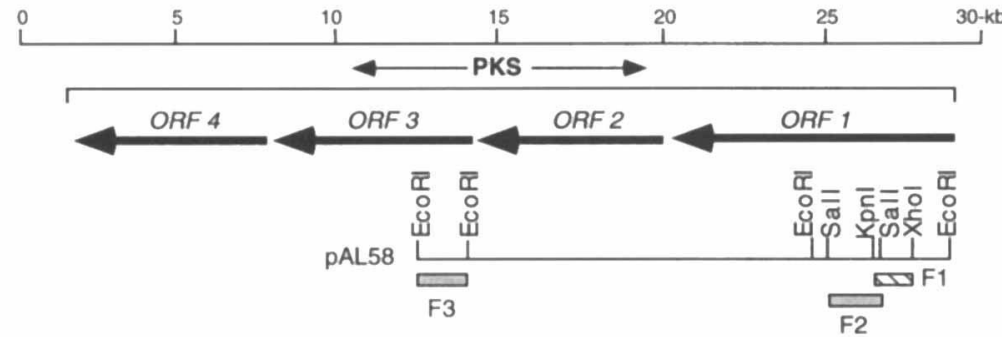

(c)

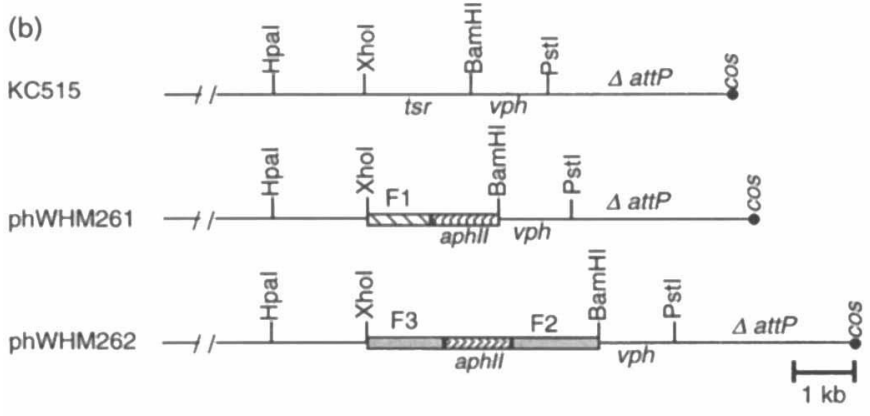

WMH1598

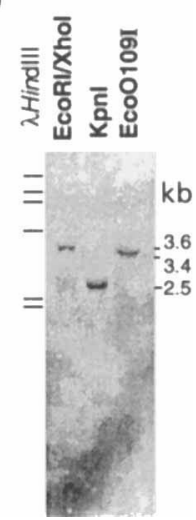

Fig. 1. (a) Organization of a gene cluster for the first modular PKS of unknown function in S. hygroscopicus ATCC 29253. The direction of gene expression and relative sizes of the ORFs are indicated by arrows. The three segments of the region in pAL58 that were used for cloning into the KC515 vector are shown beneath a restriction map showing only the sites of interest. (b) Structure of $\mathrm{KC515}$ and the two phages constructed from it using segments $F 1, F 2$ and F3. $\triangle a t t P$ and cos indicate the relative locations of the deletion in the attachment site and the cohesive ends of $\phi \mathrm{C} 31 ;$ aphll, tsr and $v p h$ are defined in the text. (c) Southern blot hybridization analysis of the genomic DNA from the WMH1598 recombinant clone resulting from infection with phWHM262. WMH1598 DNA was digested with Kpnl, Eco01091 or Xhol + EcoRl and probed with a fragment containing the aphll gene.

\section{Characterization of $\boldsymbol{S}$. hygroscopicus recombinant clones after infection with KC515 derivatives}

Since the chemical structures of rapamycin and nigericin are consistent with the involvement of a modular PKS in their biosynthesis, DNA segments from the rapamycin PKS genes (Fig. 3a) (Schwecke et al., 1995) and two other regions found to contain putative modular PKSs (Figs 1a and 2a) (X. Ruan, D. L. Stassi, N. Lomovskaya, L. Fonstein, C. R. Hutchinson \& L. Katz, unpublished) were cloned into the attP phage vector KC515 to perform gene-disruption and gene-replacement experiments. KC515 can transduce a host strain to drug resistance only when it carries an insert capable of homologous recombination with the host DNA.

The function of the genes encoding four modules of a putative type I PKS shown in Fig. 1(a) was examined first, by infection with phWHM261 and phWHM262. As expected, phWHM261 produced only clones re- 
(a)

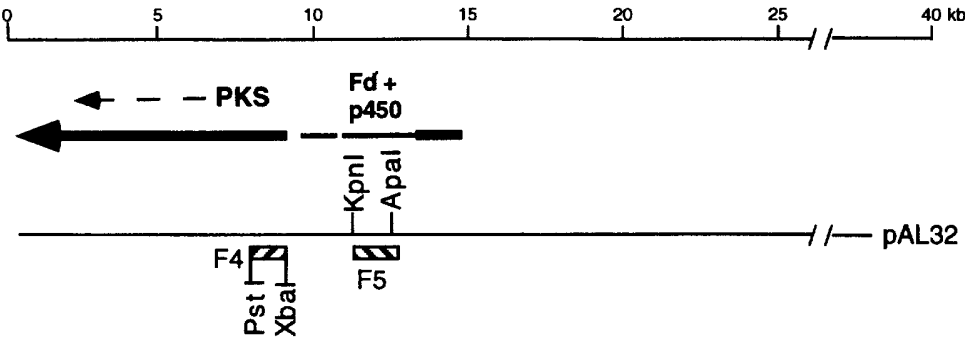

(b)

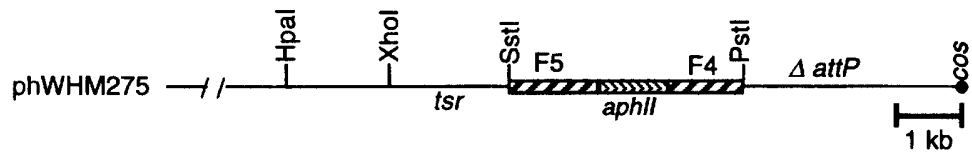

Fig. 2. (a) Organization of a gene cluster for the second modular PKS of unknown function in S. hygroscopicus ATCC 29253 together with the putative ferredoxin (Fd) and cytochrome P450 genes. The direction of PKS gene expression is indicated by an arrow. The two segments of the region in pAL32 that were used for cloning into KC515 are shown beneath a restriction map showing only the sites of interest. (b) Structure of the phWHM275 phage constructed from segments F4 and F5. All other abbreviations are as in Fig. 1. (a)
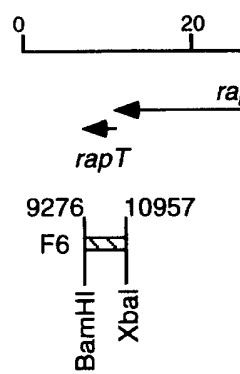

(b)

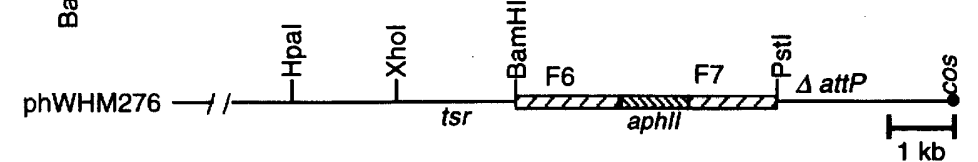

Fig. 3. (a) Organization of the $\operatorname{rap} A B C P$ PKS and $\operatorname{rap} T$ ketoreductase-dehydrogenase genes for rapamycin biosynthesis according to Schwecke et al. (1995). The direction of gene expression and relative sizes of the ORFs are indicated by arrows. The two segments of the region used to construct phWHM276 are shown beneath the ORFs that contain them and their ends are numbered according to the GenBank sequence file $X 86780$. These two segments are not drawn to scale. (b) Structure of the phWHM276 phage constructed from segments F6 and F7. All other abbreviations are as in Fig. 1.

Table 2. Clones obtained after infection of $S$. hygroscopicus with recombinant phages

\begin{tabular}{|llr|}
\hline Recombinant phage & \multicolumn{1}{c|}{ Phenotype of clones } & No. of clones \\
\hline phWHM261 & Neomycin + viomycin resistant & 111 \\
& Neomycin resistant + viomycin sensitive & 0 \\
phWHM262 & Neomycin + viomycin resistant & 310 \\
& Neomycin resistant + viomycin sensitive & 91 \\
phWHM275 & Neomycin + thiostrepton resistant & 168 \\
& Neomycin resistant + thiostrepton sensitive & 44 \\
phWHM276 & Neomycin + thiostrepton resistant & 188 \\
& Neomycin resistant + thiostrepton sensitive & 30 \\
\hline
\end{tabular}

sistant to both neomycin and viomycin due to the result of a single crossover recombination (Table 2). The presence of the integrated prophage had no obvious effect on morphological development and sporulation. After infection with phWHM262, two types of recombinant clones were obtained as a result of a single (neomycin/viomycin-resistant clones) or double (neomycin-resistant clones) crossover recombination (Table 2).

Southern analysis of the genomic DNA from representative neomycin-resistant WMH1598 (from phWHM262) as well as neomycin- and viomycin- resistant WMH1597 (from phWHM261) strains was performed to confirm recombination between the cloned fragments and genomic DNA. The $1.1 \mathrm{~kb}$ PstI-BamHI fragment of pFDNeoS containing the aphII gene was used as a probe. When XboI-NcoI (not shown), EcoRI-Xhol, KpnI or Eco0109I-digested DNA from the WMH1598 strain was analysed, $3.25 \mathrm{~kb}$ Xhol-Ncol (not shown), $3.6 \mathrm{~kb}$ EcoRI-XhoI, $2.5 \mathrm{~kb} K p n \mathrm{I}$ and $3.4 \mathrm{~kb}$ Eco0109I fragments were detected with the aphII probe (Fig. 1c), as expected, confirming the presence of a $10.9 \mathrm{~kb}$ deletion between the $\mathrm{SalI}$ and EcoRI sites as a result of a double crossover. This result indicated that replacement of the $14.1 \mathrm{~kb}$ fragment containing ORF2 
(a)

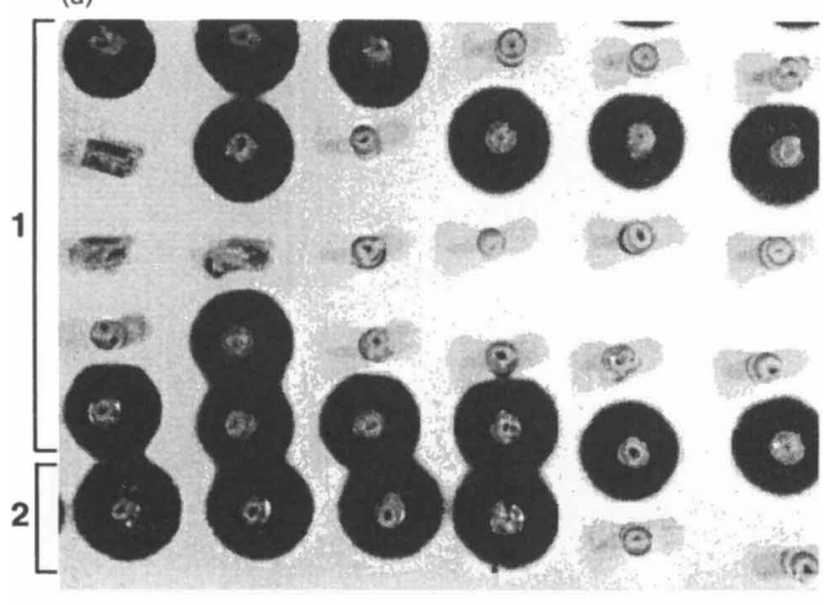

(b)

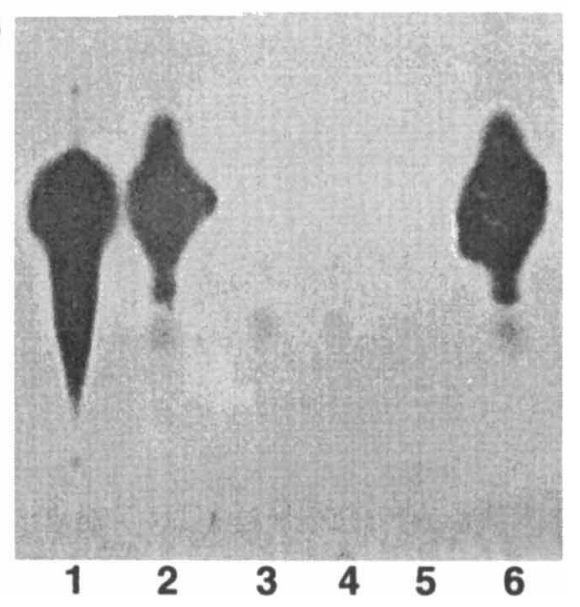

Fig. 4. Biological activity of $S$. hygroscopicus recombinant clones obtained after infection with the phWHM276 phage. (a) 1, Recombinant clones resistant to neomycin did not produce zones of inhibition whereas ones resistant to neomycin and thiostrepton did when they were tested by the agar plug method against Aspergillus niger. 2, S. hygroscopicus ATCC 29253 control (first four plugs). (b) Bioautography of culture extracts for the wild-type strain and neomycin-resistant $S$. hygroscopicus clones with $A$. niger. Lane 1, rapamycin standard; lanes 2 and 6, S. hygroscopicus ATCC 29253; lanes 3 to 5, neomycin-resistant S. hygroscopicus WMH1651, WMH1652 and WHM1653, respectively.

and part of ORF1 with the insert cloned in phWHM262 had taken place in the WMH1598 chromosome. Disruption of ORF1 was demonstrated when EcoRIBamHI-, BglII- or MluI-BamHI-digested genomic DNA from the WMH1597 strain was analysed. Since hybridizing bands of $3.0,3.4$ and $2.7 \mathrm{~kb}$ were identified (data not shown), the WMH1597 strain was produced as a result of single crossover between the cloned fragment and recipient chromosome within the $1 \cdot 1 \mathrm{~kb}$ Xhol-KpnI region of Fig. 1(a).

Similarly, the function of another set of $S$. bygroscopicus genes encoding a putative modular PKS plus a ferredoxin and a cytochrome P450 hydroxylase, shown in Fig. 2(a), were examined by a gene replacement experiment. The genotype of the recombinant strains obtained with phWHM275 was not analysed, but the data above for the two other sets of recombinants suggest on the basis of the phenotypes given in Table 2 that part of the beginning of the PKS gene and all of the ferredoxin and P450 genes should have been deleted in these strains.

Since the rapABCP genes were proposed to govern assembly of the macrolide ring of rapamycin (Schwecke et al., 1995), phage phWHM276 was designed for deletion of the rapAP genes and most of $r a p B$ and rapC (Fig. 3a). Following infection of $S$. bygroscopicus with phWHM276, clones resistant to neomycin as well as ones resistant to neomycin and thiostrepton were isolated (Table 2). PCR analysis of the chromosomal DNA from the representative WHM1651 and WHM1652 neomycin-resistant strains confirmed replacement of the $81.4 \mathrm{~kb}$ fragment containing the rap PKS genes with the $4 \cdot 1 \mathrm{~kb}$ insert cloned in phWHM276 since the expected $1.5 \mathrm{~kb}$ fragment containing a portion of the $3^{\prime}$ end of $r a p B$, aphII and the $3^{\prime}$ end of $r a p C$ was found and had the expected restriction map (data not shown).

\section{Biological activity of the recombinant clones}

Representatives of the recombinant clones obtained from the above three sets of experiments were tested by the agar plug method for the presence of biological activity against Aspergillus niger (rapamycin production) and Staphylococcus aureus (nigericin production). All the clones obtained from phWHM276 (Fig. $3 \mathrm{~b})$ that were resistant to neomycin and 18 clones resistant to neomycin and thiostrepton were tested by the agar plug method for rapamycin production. The neomycin-resistant clones did not produce zones of inhibition but the clones resistant to both antibiotics were active against $A$. niger (Fig. $4 a$ ). Specific loss of rapamycin (Fig. 4b) but not nigericin production was established by bioautography of three representative culture extracts (data not shown). In contrast, all of the clones with disruptions or deletions in the two other PKS regions (Figs 1a and 2a) produced zones of inhibition of the two indicator strains, which suggested that the clones still made rapamycin and nigericin. This was confirmed by bioautography of culture extracts only for those clones whose genotype had been verified by Southern analysis; all clones exhibited antibiotic activity comparable to that of rapamycin against $A$. niger, as well as activity against $S$. aureus or red blood cells lysis corresponding to nigericin.

Specific deletion of the PKS predicted to be involved in rapamycin biosynthesis resulted in the loss of rapamycin production. In contrast, disruption or deletion of either of the two other PKS regions had no effect on the production of rapamycin or nigericin, a polyether antibiotic also produced by $S$. hygroscopicus, but it is not clear whether the production of some other compound was lost. The method described here for introducing DNA into ATCC 29253 should allow exploration 
of the nature of the metabolites produced by the two other gene clusters as well as the possibility of manufacturing novel rapamycins.

Development of an effective system based on $\phi \mathrm{C} 31$ for introducing DNA into S. hygroscopicus will greatly facilitate further characterization of the rapamycin biosynthesis genes (Schwecke et al., 1995) and attempts to modify them for the production of novel forms of this important immunosuppressive agent. Despite the absence of a visible lytic response to phage infection, single and double lysogens of S. hygroscopicus ATCC 29253 were produced, and KC515 derivatives were shown to undergo homologous recombination via mechanisms resulting in gene disruption or replacement. Therefore, KC515 and other $\phi$ C31 derivatives will be useful for targeted mutation of the genes governing the biosynthesis of rapamycin and nigericin. These vectors can also be used in further investigations of the two other regions containing modular PKS genes, since current data suggest that these genes may be responsible for novel metabolites. Moreover, the results of our work support the wisdom of considering $\phi \mathrm{C} 31$ derivatives for gene cloning and mutation in other Streptomyces spp. because of the wide host range and versatility of these vectors (Lomovskaya et al., 1972, 1980; Chater, 1986; Hopwood et al., 1987).

\section{ACKNOWLEDGEMENTS}

We are grateful to Michael Staver for preparing a genomic library of S. hygroscopicus ATCC 29253. This work was supported in part by a grant from the National Institutes of Health (GM46696).

\section{REFERENCES}

Aparico, J. F., Molnar, I., Schwecke, T., Konig, A., Haydock, S. F., Khaw, L. E., Staunton, J. \& Leadlay, P. F. (1996). Organization of the biosynthetic gene cluster for rapamycin in Streptomyces bygroscopicus: analysis of the enzymatic domains in the modular polyketide synthase. Gene 169, 9-16.

Buttner, M. J. \& Lewis, C. G. (1992). Construction and characterization of Streptomyces coelicolor A3(2) mutants that are deficient in the nonessential $h r d$-encoded RNA polymerase sigma factor. J Bacteriol 174, 5165-5167.

Buttner, M. J., Chater, K. F. \& Bibb, M. J. (1990). Cloning, disruption, and transcriptional analysis of three RNA polymerase sigma factor genes of Streptomyces coelicolor A3(2). J Bacteriol 172, 3367-3378.

Chakraburtty, R., White, J., Takano, E. \& Bibb, M. J. (1996). Cloning, characterization and disruption of a (p)ppGpp synthetase gene (relA) of Streptomyces coelicolor A3(2). Mol Microbiol 19, 357-368.

Chater, K. F. (1986). Streptomyces phages and their application to Streptomyces genetics. In The Bacteria, vol. IX, Antibiotic producing Streptomyces, pp. 119-158. Edited by S. E. Queener \& L. E. Day. Orlando, FL: Academic Press.

Chater, K. F. \& Bruton, C. J. (1983). Mutational cloning in Streptomyces and the isolation of antibiotic production genes. Gene 26, 67-78.

Chater, K. F. \& Bruton, C. J. (1985). Resistance, regulatory and production genes for the antibiotic methylenomycin are clustered. EMBO J 4, 1893-1897.

Chater, K. F., Lomovskaya, N. D., Voeykova, T. A., Sladkova, I. A., Mkrtumian, N. M. \& Muravnik, G. L. (1986). Streptomyces $\phi$ C31like phages: cloning vectors, genome changes and host range. In Biological, Biochemical and Biomedical Aspects of Actinomycetes. Proceedings of the Sixth International Symposium on Actinomycete Biology, pp. 45-53. Edited by G. Szabo, S. Biro and M. GoodFellow. Budapest: Academic Kvado.

Cortes, J., Wiesmann, K. E. H., Roberts, G. A., Brown, M. J. B., Staunton, J. \& Leadlay, P. F. (1995). Repositioning of a domain in a modular polyketide synthase to promote specific chain cleavage. Science 268, 1487-1489.

Denis, F. \& Brzezinski, R. (1991). An improved aminoglycoside resistance gene cassette for use in Gram-negative bacteria and Streptomyces. FEMS Microbiol Lett 81, 261-264.

Donadio, S., McAlpine, J. B., Sheldon, P. J., Jackson, M. \& Katz, L. (1993). An erythromycin analog produced by reprogramming of polyketide synthesis. Proc Natl Acad Sci USA 90, 7119-7123.

Dumont, F. J. \& Su, Q. (1996). Mechanism of action of the immunosuppressant rapamycin. Life Sci 58, 373-395.

Hatanaka, H., Kino, T., Miyata, S., Inamura, N., Kuroda, A., Goto, T., Tanaka, H. \& Okuhara, M. (1988). FR-900520 and FR-900523, novel immunosuppressants isolated from a Streptomyces. II. Fermentation, isolation and physico-chemical and biological characteristics. J Antibiot 41, 1592-1601.

Hopwood, D. A., Kieser, T., Wright, H. M. \& Bibb, M. J. (1983). Plasmids, recombination and chromosomal mapping in Streptomyces lividans 66. J Gen Microbiol 129, 2257-2268.

Hopwood. D. A., Bibb, M. J., Chater, K. F., Kieser, T., Bruton, C. J., Kieser, H. M., Lydiate, D. J., Smith, C. P., Ward, J. M. \& Schempf, H. (1985). Genetic Manipulation of Streptomyces : a Laboratory Manual. Norwich: John Innes Foundation.

Hopwood, D. A., Bibb, M. J., Chater, K. F. \& Kieser, T. (1987). Plasmid and phage vectors for gene cloning and analysis in Streptomyces. Methods Enzymol 153, 116-165.

Hutchinson, C. R. (1994). Drug synthesis by genetically engineered microorganisms. Bio/Technology 12, 375-380.

Hutchinson, C. R. \& Fujii, I. (1995). Polyketide synthase gene manipulation: a structure-function approach in engineering novel antibiotics. Annu Rev Microbiol 49, 201-238.

Kao, C. M., Luo, G., Katz, L., Cane, D. E. \& Khosla, C. (1994). Engineered biosynthesis of a triketide lactone from an incomplete modular polyketide synthase. J Am Chem Soc 116, 11612-11613.

Katz, L. \& Donadio, S. (1993). Polyketide synthesis: prospects for hybrid antibiotics. Annu Rev Microbiol 47, 875-912.

Kino, T., Hatanaka, H., Miyata, S., Inamura, N., Hishiyama, H., Yajima, T., Goto, T., Okuhara, M., Kohsaka, M., Aoki, H. \& Ochiai, T. (1987). FK-506, a novel immunosuppressant isolated from a Streptomyces. II. Immunosuppressive effect of FK-506 in vitro. J Antibiot 40, 1256-1265.

Lomovskaya, N. D., Mkrtumian, N. M., Gostimskaya, N. C. \& Danilenko, V. N. (1972). Characterization of temperate actinophage $\phi$ C31 isolated from Streptomyces coelicolor A3(2). J Virol 9, 258-262.

Lomovskaya, N. D., Chater, K. F. \& Mkrtumian, N. M. (1980). Genetics and molecular biology of Streptomyces bacteriophages. Microbiol Rev 44, 206-229.

Lomovskaya, N., Hong, S.-K., Kim, 5.-U., Fonstein, L., Furuya, K. \& Hutchinson, C. R. (1996). The Streptomyces peucetius $\operatorname{drr} C$ gene encodes a UvrA-like protein involved in daunorubicin resistance and production. J Bacteriol 178, 3238-3245. 
Melino, M. R. \& Sigal, N. H. (1990). Distinct mechanisms of suppression of murine $\mathrm{T}$ cell activation by the related macrolides FK-506 and rapamycin. J Immunol 144, 251-258.

Mendez, C. \& Chater, K. F. (1987). Cloning of whiG, a gene critical for sporulation of Streptomyces coelicolor A3(2). J Bacteriol 169, 5715-5720.

Pahe, A. \& Keller, U. (1992). FK506-binding proteins from streptomycetes producing immunosuppressive macrolactones of the FK-506 type. J Bacteriol 174, 5888-5894.

Piret, J. M. \& Chater, K. F. (1985). Phage-mediated cloning of bldA, a region involved in Streptomyces coelicolor morphological development, and its analysis by genetic complementation. $J$ Bacteriol 163, 965-972.

Sambrook, J., Frisch, E. F. \& Maniatis, T. (1989). Molecular Cloning: a Laboratory Manual. NY: Cold Spring Harbor Laboratory.
Schwecke, T., Aparicio, J. F., Molnar, I., Konig, A., Khaw, L. E., Haydock, S. F., Oliynyk, M., Caffrey, P., Cortes, J., Lester, J. B., Bohm, G. A., Staunton, J. \& Leadlay, P. F. (1995). The biosynthesis gene cluster for the polyketide immunosuppressant rapamycin. Proc Natl Acad Sci USA 93, 7839-7843.

Vezina, C., Kudelski, A. \& Sehgal, S. N. (1975). Rapamycin (AY22,989), a new antifungal antibiotic. I. Taxonomy of the producing streptomycete and isolation of the active principle. $J$ Antibiotics 28, 721-726.

Yanisch-Perron, C., Vieira, J. \& Messing, J. (1985). Improved M13 phage cloning vectors and host strains: nucleotide sequences of the M13 mp18 and pUC19 vectors. Gene 33, 103-119.

Received 29 July 1996; revised 9 October 1996; accepted 21 October 1996. 